Millatī, Journal of Islamic Studies and Humanities

Vol. 5, No. 1, June 2020: p. 51-64. DOI: 10.18326/mlt.v5i1. 51-64

p-ISSN : 2541-3627; e-ISSN 2540-9964

Website: http://millati.iainsalatiga.ac.id/index.php/millati/index

\title{
Muslim's Responses to Believers of Indigenous Faiths
}

\author{
Lina Kushidayati \\ IAIN Kudus \\ Author.email.adress@mail.com
}

Moh Rosyid

IAIN Kudus

mrosyid72@yahoo.co.id

\begin{abstract}
By using interview and observation followed by a descriptive qualitative analysis, this manuscript was written to describe the author's mentoring efforts and the Muslim response in Kudus of eight believers of indigenous faith (penghayat kepercayaan). Based on Constitutional Court's Decision Number 97/PUU-XIV/2016, it is stated that indigenous faith believers are equal to religion. Therefore, they responded by changing the column of religion into believers of indigenous faith on their Resident Identity Card (KTP). Attaching a hyphen (-) in their ID card is perceived by people of Persada and Samin as a denial of admission. In contrast, the other six believers keep writing Islam as their religion since they think that by changing their religion into believers of indigenous faith would raise some anxieties, such as (1) being refused in the public cemetery, (2) being treated discriminately by the institution or company when their children seek a job, and (3) finding difficulty in seeking a marriage partner, especially for women. Besides, their existence has been regarded as a spiritual organization which is not related to religion status.
\end{abstract}

Keywords: believer of indigenous faith, consistency, fear of admission, and middle way

\begin{abstract}
Manuskrip ini bertujuan untuk mendeskripsikan usaha penulis dalam memberi pemahaman kepada delapan kelompok penghayat kepercayaan di Kabupaten Kudus beserta respon Muslim terhadapnya. Penelitian ini dilakukan dengan pendekatan analisis kualitatif deskriptif mengunakan metode wawancara dan observasi. Berdasarkan Keputusan Mahkamah Konstituni No. 97/PUU-XIV/20016 yang menyatakan bahwa penghayat kepercayaan setara dalam hal keagamaan. Sehingga, mereka kemudian mengubah kolom agama pada Kartu Tanda Penduduk (KTP) mereka menjadi penghayat kepercayaan. Menggunakan tanda strip (-) pada KTP mereka merupakan salah satu wujud penolakan bagi penghayat kepercayaan Persada dan Samin. Sebaliknya, keenam kelompok penghayat kepercayaan tetap menulis Islam sebagai agama mereka karena menurut mereka, dengan mengubah agama mereka dapat menimbulkan beberapa keresahan meliputi (1) penolakan pada pemakaman umum, (2) perlakuan diskriminatif bagi anak-anak mereka yang mencari pekerjaan, dan (3) kesulitan dalam mencari pasangan hidup, terutama bagi penghayat kepercayaan wanita. Selain itu, keberadaan mereka dianggap sebagai organisasi spiritual yang tidak terkait dengan status keagamaan.
\end{abstract}

Kata kunci: penghayat kepercayaan, konsistensi, ketakutan akan penerimaan, dan jalan tengah 
Millatī, Journal of Islamic Studies and Humanities, Vol. 5, No. 1, June 2020: 51-64

\section{INTRODUCTION}

According to data from the Director General of Civil Registry of the Ministry of Home Affairs per June 30, 2017, the number of Indonesian residents who registered themselves as believers of indigenous faith was 138,791 people. The number is 3.14 percent compared to the population data which register themselves as the followers of six religions (Islam, Christianity, Catholicism, Hinduism, Buddhism and Confucianism). There are 187 organizations of indigenous faith believers in which 160 are active and 27 are inactive spreading out in 13 provinces including Sumatera Utara (12 groups), Riau (1 group), Lampung (5 groups), Banten (1 group), DKI Jakarta (14 groups), West Java (7 groups), Central Java (53 groups), Yogyakarta (25 groups), East Java (50 groups), Bali (8 groups), NTB (2 groups), NTT (5 groups), and North Sulawesi (4 groups).

This manuscript focuses on Kudus, Central Java where there are eight groups namely Budi Lubur, Hardo Pusoro, Sapto Darmo, kawrub kodrating pangeran, sumarah, pramono sejati, subud, and Sikep Samin. The believers were portrayed in the aspect of their efforts to respond to formal education rights and the perception of the Constitutional Court's Decision on the Religious Column in the Resident Identity Card (KTP). Apparently, it was only Sapta Darma and Sikep Samin who changed the religion column in their ID card (originally striped then was changed into indigenous faith believer). Therefore, this manuscript studies why and the reason the six believers were passive.

Besides, in formal education, there were only one student who was from a resident of Sapto Darmo that originally received Islamic course which become a course of indigenous faith taught by a teacher though it did not happen in class. Moreover, as Sikep Samin wanted to get a course of indigenous faith but there were no Samin residents who fulfilled the requirements to be a teacher, therefore, they were taught Christian religion since there were only Christian and Islamic teachers on their school. Additionally, on Islamic course, the children of Samin residents were unable to respond to the education since arabic is used in the course.

\section{METHODS}

According to Mudzhar, the symptoms of religion (in this manuscript, focusing on the indigenous faith believers) can be examined from some aspects including (1) scripture: 
manuscripts, sources of teachings, religious symbols, (2) adherents, leaders (thoughts, attitudes, and behaviors) actualize their teachings/beliefs, (3) rites, institutions, customs, such as the way of worship or marriage, (4) tools in the form of places of worship, bells, caps, etc., and (5) religious organizations. ${ }^{1}$ This study examines the attitudes of the indigenous faith believers in Kudus after the decision of the Constitutional Court (MK) Number: 97/PUU-XIV/2016 which aligns the believers with religion so that the column of religion which was originally written as hyphen transforming into the indigenous faith believers in God Almighty. The data of this study were obtained by interview and observation with a qualitative descriptive analysis.

\section{DISCUSSION}

\section{Map of the Believers of Indigenous Faith in Kudus}

The groups of indigenous faith believers in Kudus until June 2019 are eight groups including Budi Lubur, Hardo Pusoro, Sapto Darmo, kawrub kodrating pangeran, sumarah, pramono sejati, subud, and Sikep Samin. The characters are (1) organized (arranging regular and periodic meetings), (2) non-organized (arranging regular meetings), and (3) individuals. First, located in nonpermanent studio (the room in the PKKP residents' house) functioned as a studio (meeting and worship place), Paguyuban Kaweruh Kodrating Pangeran (PKKP) do the prayer activities every Friday night except Friday night of Wage. Second, the Association of Sapta Darma (Persada) meets every Friday night at the house of the Persada residents in turns. Third, Sumarah does their activities every Sunday night by moving around at the house of Sumarah residents. Fourth, Subud conduct their activities every month at the house of Subud residents alternately. Fifth, Sikep Samin (Sedulur Sikep) which originally had activities every forty days (selapan) changed into intermitten program since many of them work as building constructors wandered to the big city. However, the other indigenous faith believers (Budi Lubur, Hardo Pusoro, and Pramono sejati) do not hold regular meetings because the elders and the residents are lack of concern for their organizational meetings.

The meeting material discussed by the residents in the routine meetings vary from community to community including wulangreh, pasujutan, semedi, mental training, and deliberation. The meeting places for routine meetings is in a resident' house due to anticipation

\footnotetext{
${ }^{1}$ H.M. Atho Mudzhar. Pendekatan Studi Islam dalam Teori dan Praktek. (Yogyakarta: Pustaka Pelajar, 1998)
} 
Millatī, Journal of Islamic Studies and Humanities, Vol. 5, No. 1, June 2020: 51-64

of being questioned by the majority religious community because they do not have the permission to build a studio. Some of the residents think that there is no need for a studio because God is everywhere to be worshiped.

Because the residents of indigenous faith fulfill their busy life in the workplace, the meeting among them is not carried out. However, when they get an invitation from the Culture and Tourism Agency of Kudus Regency, the meeting is held. Moreover, there is no organizational awareness among the indigenous faith believers as a result of suspicion of the surrounding community and the government's restrictive regulation, such as the existence of a supervisory body of public indigenous faith (PAKEM). According to Stange, the believers became a 'thorn in the flesh' for orthodox Muslims. ${ }^{2}$ Even in Kudus, this situation still happens. As a result, there are groups of the believers who do not register themselves in the Office of National Unity and Politics (Kesbangpol) of Kudus, they are Normanto and Pangestu. These people do not want to be bureaucratic and they think that religiousity/belief is symbolic. According to Endraswara, for the Javanese, the world contains a symbol that is contemplated by its condition to communicate with God. So, religion is a symbol used in carrying out Javanese religion. ${ }^{3}$

\section{Formal Education and of Indigenous Faith Believer in Kudus}

Director General of Culture, Hilmar Farid said that statistically, the number of indigenous faith believers has not yet been ascertained, even though residents of the believers said that there are around 12 million people. The data from the Noble Assembly (Majelis Luhur) of the Belief in God of Indonesia (MLKI) ${ }^{4}$ states that there are currently 184 groups of the indigenous faith believers in the central level. The indigenous faith believers claim that around 60 percent of students at school require an indigenous faith education curriculum. The Director of Development of Belief in God Almighty and Tradition, the Ministry of Education and Culture, Sri Hartini said, the compilation of education curricula for people is mandated by Minister of Education and Culture's Regulation Number 27 Year 2016 concerning Educational Services to

\footnotetext{
2 Paul Stange. Politik Perhatian Rasa dalam Kebudayaan Jawa. (Yogyakarta: LKiS, 1998), p. 242.

${ }^{3}$ Suwardi Endraswara. Agama Jawa Ajaran, Amalan, dan Asal-Usul Kejawen. (Yogyakarta : Narasi, 2015).

${ }^{4} \mathrm{MLKI}$ is a national association of indigenous faith organizations in Indonesia to facilitate, accommodate the struggle of indigenous faith organizations and its constitutional rights.
} 
Indigenous Faith Believer in the school level. Article 2 states that the content of indigenous faith education must have core and basic competencies prepared by MLKI. ${ }^{5}$

On 6 and 7 September 2016 MLKI prepares the design of curriculum or educational teaching material for indigenous faith believers from the basic to high level and equal level of school. The curriculum material includes (1) four national consensus, i.e. Pancasila, UUD 1945, Bhinneka Tunggal Ika, NKRI, and (2) based on 18 national characters and understanding of the culture of Nusantara (Indonesian Arhipelago) from spiritual aspect. The curriculum prioritizes the understanding of diversity because the indigenous faith believers are very diverse. The curriculum design was submitted to the Director General of Culture, Ministry of Education and Culture, which was subsequently approved by the Ministry of Education and Culture Center of Curriculum and Books. According to Minister of Education and Culture's Regulation Number 27 of 2016 Article 2, the content of education must have core competencies and bases compiled by MLKI. MLKI in Kudus Regency is formed based on Decree of MLKI Central Java No S.Kept.021/DMW.Jateng/III/2018 dated March 302018. Until the writing of this manuscript, the management of the MLKI Kudus has never conducted a meeting among the residents of the congregation due to various factors that needs exploration.

\section{Course of Indigenous Faith Believer for the Residents of Sapta Darma and Samin}

Education plays a major role as the foundation of one's intelligence for life and as a source of knowledge for students. Therefore, Sapta Darmayang Residents whose children go to formal school want the availability of indigenous faith teachers, not religion teachers (one of the six religions). The availability of teacher is fulfilled by a teacher who is also a resident of Sapta Darma from Mayong Lor Village, Mayong Subdistrict, Jepara Regency, not from Kudus because there are no indigenous faith teachers from Kudus. The learning process is not in the classroom since there is only one student. The learning material given by the teacher includes Faith education (Sapta Darma) and character building. The student is now in the 8th grade of Junior High School of SMPN 2 Kudus. The parents of the child who are also Chairperson of the Association of Sapta Darma (Persada) in Kudus accepts the situation in which there is no

\footnotetext{
${ }^{5}$ Kompas, 8 September 2016.
} 
Millatī, Journal of Islamic Studies and Humanities, Vol. 5, No. 1, June 2020: 51-64

classroom learning activity. He hoped that in time there would be classes provided by the principal. This character, according to the author, was inspired by the understanding of the resident of Persada, Nurlan, as directed by the teaching of wewarah pitu wajibing warga Sapta Darma (the seven teachings of Sapto Darma) on point (5) "Wani Urip Kanthi Kapitayan Saka Kekuwatane Dhewe" (dared to live in full confidence in one's own strength) and (6) "tanduke marang warga bebrayan kudu susila, kanthi alusing budi pakarti tansah agawe pepadhang tan mareming liyan" (living in a community should be with a good morality accompanied by subtle character. ${ }^{6}$ The author on Thursday, April 23, 2019 communicated directly with the Deputy Regent of Kudus that the children of member of Persada who are studying in SMPN 2 Kudus had not received the indigenous faith course in the classroom, even though the teacher is available. This is because the principal of the public junior high school (SMPN 2) has not facilitated classrooms for learning. In practice indigenous faith teacher only handed out learning materials and conducted tests to assess students' comprehension. Responding to this, Nurlan hoped that the author would not continue the negotiations so as not to cause offense to the Principal of the public school (SMPN 2 Kudus).

For the children of Sapta Darma residents and other indigenous faith believers who go to formal schools beside SMPN 2 Kudus, the course is not given by the indigenous faith teacher, or without indigenous faith learning material. This is because the residents of Persada Kudus acknowledged that the child was not psychologically ready and are worried of being sneered by his peers for being an indigenous faith believer. This can make the child unwilling to go to school. In order to avoid these situations, children of Sapta Darma believers get the course of Islamic religion. This concern was very much triggered by parents who did not try to provide psychological provisions to their children who go to formal school and only argued that they did not want to bring up new problems.

It is different from indigenous faith education for Samin residents who want to be taught by Samin's teacher in formal schools with Samin's learning material. The problem is that there are no Samin residents with bachelor's degrees, and most of them are only high school and vocational school graduates. Regarding to this condition, Christian course is then chosen since it is considered easier than Islamic course which is regarded difficult due to the Arabic

\footnotetext{
${ }^{6}$ See in the book written by Sri Pawenang, Wewarah Kerokhanian Sapta Darma jilid I, published by Sekretariat Tuntunan Agung Unit Penerbitan Jalan Surokarsan MG II/472 Yogyakarta, t.th, p.23.
} 
language material. Schools in which Samin children are enrolled only provide Islamic course and Christian course due to the availability of the religion teachers.

\section{Indigenous Faith Education for the Believers Except Sapta Darma and Samin}

It is not all of indigenous faith residents in Kudus who have children in compulsory education since their children are already married. However, for other residents, except Sapta Darma and Samin, who have children attending formal school, they attend Islamic religion course due to the fact that having many friends and teachers of other Islam religion are not always available at school. In addition, the identity as indigenous faith believers are not sturdy.

\section{The Believers' Response in Kudus towards the Decision of the Constitutional Court concerning the Column of Religion in Resident Identity Card (KTP)}

The groups of indigenous faith believers in Kudus who are concerned by the Constitutional Court's (MK) Decisions about the writing of the indigenous faith believer in the religion column of the identity card (KTP) give two responses. The first response is changing the column of religion on the ID card which was originally hyphen and written in Islam to the indigenous faith believers. These responses are from some residents of Sapta Darma (Persada) (9 persons) and some residents of Samin (20 persons).

The second response is keeping Islam in the religion column of the identity card (KTP). These responses are from other residents of indigenous faith, except Sapta Darma and Samin. This is a safe choice because first, tension between religion and followers of indigenous faith has not subsided. According to Subagya, the relationship between kebatinan (indigenous faith) and religion is one of the most sensitive, contentious, and even destructive, because kebatinan (indigenous faith) and religion lead to an absolute value. Those things seek to guess and answer the last secret of life, based on their beliefs. ${ }^{7}$ The trigger for the tension between those two according to the author is because the teachings are sometimes similar. According to Damami, the similarities are in terms of teachings and cults (worship) or behavior. ${ }^{8}$ The Similarity of

${ }^{7}$ Rahmat Subagya. Kepercayaan, Kebatinan, Kerohanian, Kejiwaan, dan Agama, (Yogyakarta: Kanisius, 1976), p. 67.

${ }^{8}$ Mohammad Damami. Kepercayaan terhadap Tuban Yang Maha Esa pada Periode 1973-1983 sebuah Sumbangan Pemahaman tentang Proses Legalisasi Konstitusional dalam Konteks Pluralitas Keberagamaan di Indonesia, (Jakarta: Balitbang dan Diklat Kemenag RI, 2011), p. 65. 
Millatī, Journal of Islamic Studies and Humanities, Vol. 5, No. 1, June 2020: 51-64

teaching in the analysis of the author are varied. First, slametan, in the perspective of nahdliyin Muslims, is religious teachings (charity) acculturated with tradition. Second, tilik kubur (grave visit), in Islam, is prescribed in sharia. According to Layungkuning, death for Javanese is not the end, but leaving the ritualization carried out by those who are still alive. ${ }^{9}$ Third, fasting which is not described in the fiqh, is including poso mutih, ngrowot. The figh only implies fasting during Ramadhan and sunnah fasting, such as fasting on Mondays and Thursdays. According to Endraswara, mystical thinking systems are usually reflected in real actions (behavior). Javanese like to practice behavior that is identical with concern, tirakat (tapa brata), tapa ngrowot (eating seedless meal), tapa ngidang (only eating vegetables), mutih (only eating rice without side dishes), all of those to cleanse themselves internally. ${ }^{10}$ Fourth, the next is tradition which is traditionalized. Subagya exemplifies in daily ceremonies such as rice harvesting, making houses, blessing/charity of the village. ${ }^{11}$ According to Musman, the universal Kejawen teachings were always attached side by side with the religion adopted in his day. ${ }^{12}$

The change into indigenous faith believer bring out some worries including the rejection of funeral procession. It is as a result of the public cemetery which is partially written "Muslim cemetery" on the board at the tomb. It raises concerns (although there has never been a rejection of the funeral of residents in the village tomb) for those who declare as the believers in the ID card would not be buried in the cemetery. Funeral procession in a government operated cemetery requires high cost of around Rp. 5 million and the site is far from the village. Choosing Islam in religion column in KTP gives indigenous faith believers access to having funeral procession held in public cemetery or waqf tombs in their villages. This concern does not occur if the residents are strong with their teachings. ${ }^{13}$ In addition, the worry comes if

\footnotetext{
9 Bendung Layungkuning. Sangkan Paraning Dumadi Orang Jawa dan Rahasia Kematian, (Yogyakarta: Narasi, 2018, p. 93.

10 Suwardi Endraswara. Mistik Kejawen Sinkretisme, Simbolisme, dan Sufisme dalam Budaya Spiritual Jawa, (Narasi: Yogyakarta, 2018), p. 8.

${ }^{11}$ Rahmat Subagya. Agama Asli Indonesia, (Jakarta, Sinar Harapan dan Yayasan Cipta Loka Caraka, 1981), p. 125.

12 Asti Musman. Agama Ageming Aji Menelisik Akar Spirituaisme Jawa, (Yogyakarta: Pustaka Jawi, 2017), p. 12.

${ }^{13}$ Local Government of Kudus has two paid public cemeteries. The availability of public cemetery is based on Ministrial Joint Decree between Ministry of Internal Affairs and Ministry of Culture and Tourism Number 43 year 2009 and Number 41 year 2009 on Indigenous Faith Believers Guideline Chapter 8 in which the deceased is buried in public cemetery. If there is a rejection as it is a wakaf cemetery, Local Government must provide the alternative cemetery.
} 
their children apply to become civil servants (PNS) or formal workers, they are not treated positively by the government/company. Furthermore, if they are going to get married, especially a girl, she has difficulty to get a marriage partner. Besides, the existence of the believers is regarded as a spiritual organization, not related to religion status in the ID card.

\section{Impact of the Change to the Writing of Religion in Resident Identity Card}

After the column of religion in his ID card was changed into penghayat kepercayaan (indigenous faith believer), some Samin's residents in Kudus who were initiated by Budi Santoso registered their marriage in the Population and Civil Registry Office to have a marriage certificate. Formerly, the marriage of Samin residents is not registered in the Population and Civil Registry Office, so they do not have a marriage certificate. Excluding the role of government (by not being registered in civil registry) according to the author, is part of the movement against colonialism. However, this movement is still maintained by some Samin residents in Kudus. For residents in Kudus except Samin, the marriage is Islamic. Moreover, for the person whose religion column has been changed into a penghayat (believer of indigenous faith), a marriage among the believers has not yet occurred in Kudus at the time of this manuscript written. This is because the Act Number 1 of 1974 requires a marriage to be of the same religion or fellow believers. Typically, they mate with their identity as Muslims who marry Muslims. In fact, there were residents in Kudus appointed by the Director General of Cultural and Film Values (NBSF) of the Director General of Culture to marry, especially the residents of Sapto Darmo. Nurlan received the certificate of trustworthy leader Number 120 / SK / Dit.Kep / NBSF / XI / 2007 dated November 1, 2007, which is valid until November 1, 2012. Furthermore, based on the Certificate of Registration of Trustees, Number 26 / SKT / PKT / KEB / 2013 dated April 11, 2013, valid until 11 April 2017, Nurlan is appointed again as the leader of the Persada community whose service areas including Kudus, Jepara and Pati. Until now, it has not received a registered certificate again at the end of 2017. The activeness of Sapto Darmo in the organization was because it was supported by his predecessor Father Sri Gutomo, a soldier in the New Order (Orba) era. It was then continued by Madam Sri Pawenang who occupied the position of group delegate in the People's Consultative Assembly (MPR) in strengthening Golkar. Sapto Darmo was struggled in the past to be recognized as a religion. 
Millatī, Journal of Islamic Studies and Humanities, Vol. 5, No. 1, June 2020: 51-64

As a result of the Court's decision, a legal entity was proposed by some Samin residents in Kudus. Initially, the request through a notary in Kudus to the Ministry of Human Rights was written 'Penghayat kepercayaan Wong Sikep Samin Agamane Adam'. This request was denied by the Ministry of Justice and Human Rights without giving any reasons. According to the author, the rejection was due to the inclusion of 'agamane Adam'. Furthermore, the residents of Samin were changed to 'Penghayat kepercayaan Wong Sikep Samin' and got an Inventarization Sign from the Director of Belief in God Almighty and Tradition, Director General of Culture Number TI.321/F.12/N.1.1/2018 dated 11 December 2018, in which Budi Santoso (Samin figure in Kudus) served as the person in charge. Furthermore, the residents of Samin proposed their figure (Budi Santoso) as the leader who was authorized to facilitate the marriage of the Samin residents. The Certificate of Registration of the Leader of Indigenous Faith by the Director of Belief in God Almighty and Tradition, Director General of Culture Number 01/SKT/KT/I/19 was then issued dated 23 January 2019 certifying that Budi Santoso is the leader of Samin. This is in accordance with Government Regulation Number 37 of 2007 concerning Implementation of the Adminduk Act Article 1 (20) which states that parental marriage certificate is made, signed, and ratified by the leader of indigenous faith.

On Thursday, April 23, 2019, a marriage ceremony was conducted for the first time for Samin residents in Kudus. It was between Anik Agustina and Kristiyono which were registered in the Office of Population and Civil Registry (Dukcapil) of Kudus. The acquisition of Samin's marriage certificate was at the time of this manuscript was completing the administration. In fact, some Samin residents who are not educated in formal institutions want to register their marriage which is not listed in the Dukcapil. They argued that they did not want to change the tradition, but still followed the unwritten teachings of Ki Samin Surosentiko. In this condition, the author is trying to explain when a marriage is not registered in which they will suffer losses from the aspect of civil administration. The government cannot record the citizenship events of the residents of Samin. Likewise, the author is trying to give understanding to the other six indigenous faith believers in Kudus who have not yet been organized and have not appointed their leaders as facilitators of marriage. During this time, the six marriages were Islamic and the column of religion in the ID card was also Islam, and their children went to formal schools and received Islamic education. The fear of claiming to be a resident of indigenous faith needed a way out. Moreover, the author has communicated directly with the Deputy Regent of 
Kudus that the children of Persada members who have been studying at Kudus Public High School have not received indigenous faith course in the classroom, even though there are available teachers. This is because the Head of the public high school has not facilitated classrooms in the learning so that only learning material is given by the teacher to the students and the examinations are assessed by the teacher of indigenous faith. In contrast, Samin residents who are in formal school, are taught Christianity (according to their choice) not Samin's belief. It happens because there is no teacher of Samin's belief. There needs to be a win-win solution that the teacher of indigenous faith is required to have a bachelor degree, while in fact Samin residents are only high school /vocational school graduates.

\section{CONCLUSION}

The existence of Eight Believers of Indigenous Faith in Kudus in responding to the right to obtain indigenous courses in learning in formal education are in two forms. The first form is receiving indigenous faith's learning process from indigenous faith teachers even though there is no learning process in the classroom but only material and assignments from the teacher. This is because the principal of SMPN 2 has not facilitated special classrooms under the pretext of only one student from Sapta Darma residents. For the Sapta Darma residents and other indigenous faith's followers receive Islamic religious courses instead of the indigenous faith course. This is because the awareness to understand their teachings are very low, unlike the Samin residents who want to receive teachings about the Samin and Samin teachers in

formal schools. However, there are no Samin residents with bachelor degrees since they are only high school/vocational school graduates, so there is no Samin teacher. In this condition, Samin residents receive Christian religious courses in the class. This is considered to be easier to understand than Islamic religious courses that have Arabic language content.

Requests for judicial review of the indigenous faith's residents on the mandate of Act Number 24 of 2013 amending the Act Number 23 of 2003 concerning civil Administration, Article 61 (2) for residents whose religion has not been recognized as a religion in accordance with the provisions of legislation or belief groups (column of religion in ID card) not filled but written hyphen (-) instead but still being served and recorded in the population database. The petition was granted by the judge of Constitutional Court Number 97 / PUU-XIV / 2016 dated October 18, 2017. It stated that the indigenous faith is equivalent to the religion and the 
Millatī, Journal of Islamic Studies and Humanities, Vol. 5, No. 1, June 2020: 51-64

religion column of the residents in the ID card is written penghayat kepercayaan (indigenous faith's believer). Originally Act No.23/2006 was amended by Law No.24/2013 concerning Civil Administration (Adminduk) Article 61 which stated that residents whose religion has not been recognized as a religion or for believers, is written hyphen (-) on the column of religion in the KTP. That the indigenous faith is equivalent to religion so that the religion column in the owner of ID card which was originally written as hyphen $(-)$ is changed into penghayat kepercayaan (indigenous faith's believer). This fulfillment for the residents of Sapta Darma and Samin changes as the Judicial Review's results with the purpose of being existent with its characteristics. The residents of Persada and Samin as disclaimers of recognition. However, the other residents wrote a column of religion in their ID card which remained Islam, the reasons are (1) it is suspectible to be responded discriminately by the environment and their families;

(2) it results in worries that if they die they would not be buried in public cemetery in the majority Muslim communities; (3) embracing religion/belief is just in the heart, as for ID cards and others are just living accessories, not something urgent.

\section{RECOMMENDATION}

From in the discussion above, it can be implied that it requires real efforts by the Kudus Local Government, leaders of the indigenous faith believers, and residents in Kudus together such as in the following; 1) Growing up awareness of organization as a medium for correcting, nurturing, fostering, and caring for residents of the community by regional government's leaders, MLKI, and community leaders to residents of indigenous faith. The growth of awareness is responsive to legal products and local government policies. The Regional Government of Kudus c.q The Department of Culture and Tourism and the Department of Education, Youth and Sports are recommended to facilitate the continuity of the organization of indigenous faith believers and optimally evaluate the learning process in formal schools according to their duties; 2) Optimizing MLKI's Performance by providing funds from the provincial and district budgets so that the objectives of establishing MLKI in the regions can be implemented; 3) The local government must be concerned in giving legal guarantees in the form of regulations so that (a) the public cemetery are not claimed by majority religious people (the non-waqf) to anticipate the worry of refusal of burial procession towards the indigenous faith's believers, (b) if the residents of believers have indigenous faith's teachers, the learning 
process in classrooms must be done regardless of the number of students; 4) With regard to this condition, the author is trying to explain when marriage is not registered, Samin residents may suffer from losses in the aspects of civil administration. The government cannot record the citizenship events of the residents of Samin. Likewise, the author is trying to give understanding to the other six indigenous faith's believers in Kudus who have not yet been organized and have not appointed their leaders as facilitators of marriage. During this time, the six marriages were Islamic and the column of religion in the ID card was also Islamic, their children were in formal schools and received Islamic education. The fear of claiming to be a resident of indigenous faith needed a way out. Therefore, the writer has communicated directly with the Deputy Regent of Kudus that the children of Penghayat (indigenous faith's believer)of Persada who have been studying in a Kudus Public High School have not received indigenous faith's courses in the classroom even though there are teachers. This is because the Principal of the High School has not facilitated classrooms in learning, so learning material can be given by the teacher to the students and the examinations are assessed by the teacher of indigenous faith. In contrast, Samin residents who are in formal school are taught Christianity (according to their choice) because there is no teacher for Samin. There needs to be a win-win solution that the teacher is required to get a bachelor degree, whereas the highest education of most Samin residents are only high school/vocational school graduates.

\section{REFERENCES}

Damami, M. (2011). Kepercayaan terhadap Tuhan Yang Maha Esa pada Periode 1973-1983 sebuah Sumbangan Pemahaman tentang Proses Legalisasi Konstitusional dalam Konteks Pluralitas Keberagamaan di Indonesia. Jakarta: Balitbang dan Diklat Kemenag RI.

Endraswara, S. (2015). Agama Jawa Ajaran, Amalan, dan Asal-Usul Kejawen. Yogyakarta: Narasi.

Endraswara, S. (2018). Mistik Kejawen Sinkretisme, Simbolisme, dan Sufisme dalam Budaya Spiritual Jawa. Yogyakarta: Narasi.

Layungkuning, B. (2018). Sangkan Paraning Dumadi Orang Jawa dan Rahasia Kematian. Yogyakarta: Narasi. 
Millatī, Journal of Islamic Studies and Humanities, Vol. 5, No. 1, June 2020: 51-64

Mudzar, M. A. (1998). Pendekatan Studi Islam dalam Teori dan Praktek. Yogyakarta: Pustaka Pelajar.

Musman, A. (2017). Agama Ageming Aji Menelisik Akar Spiritualisme Jawa. Yogyakarta: Pustaka Jawi.

Stange, P. (1998). Politik Perbatian Rasa dalam Kebudayaan Jawa. Yogyakarta: LKiS.

Subagya, R. (1976). Kepercayaan, Kebatinan, Kerohanian, Kejiwaan, dan Agama. Yogyakarta: Kanisius.

Subagya, R. (1981). Agama Asli Indonesia. Jakarta: Sinar Harapan dan Yayasan Cipta Loka Caraka. 